\title{
MODERASI BERAGAMA SEBAGAI JALAN DAKWAH MAYORITAS MUSLIM PADA MINORITAS NON MUSLIM
}

\author{
Sugianto \\ IAI An Nur Lampung Selatan \\ sugiantoalfaruqi3@gmail.com \\ Rahmat Hidayat \\ Mahasiswa Pascasarjana UIN Raden Intan Lampung \\ hidayatrahmat677@gmail.com
}

\begin{abstract}
This study discusses the expression of religious moderation of the majority (Muslim) group against the minority group (non-Muslim) in Rama Puja Village, East Lampung. In addition, the purpose of this study is to produce a formulation of the ideal and appropriate expression of Religious Moderation for Islamic societies that live in plural and multicultural social conditions. This type of research is descriptive qualitative with data collection methods through interviews, participant observation and documentation. In analyzing the data, the researcher applied a qualitative descriptive analysis technique. The expected results of the research are: the expression of religious moderation of the majority group against the minority of Rama Puja Village, East Lampung, manifested in political expressions, expressions of worship and expressions of social activities. On the basis of these findings, it can be used as a role model in religion, especially the majority against minority groups.
\end{abstract}

Keywords: Moderation; Religion; Dakwah; Muslim. 


\section{A. PENDAHULUAN}

Indonesia merupakan rumah bagi 268 juta jiwa ${ }^{1}, 31$ suku bangsa. a², 6 agama, 718 bahasa daerah yang tersebar pada 34 provinsi di Indonesia ${ }^{3}$. Komposisi tersebut sangat memungkinkan terjadinya konflik dalam masyarakat. Seperti, perdebatan benar-salah dan baik-buruk yang tidak didukung pemahaman yang mendalam dan wawasan yang luas terhadap suatu permasalahan akan menimbulkan konflik yang berkepanjangan. Konflik tersebut tidak hanya menyangkut aspek teologis semata, tetapi sudah menyebar ke berbagai aspek kehidupan, salah satunya aspek politik. Data sejarah menunjukan bahwa Islam terpecah menjadi beberapa firqoh yang dilatar belakangi oleh masalah politik ${ }^{4}$. Agak aneh kiranya jika dikatakan bahwa dalam Islam, sebagai agama, persoalan pertama yang timbul adalah aspek politik dan bukan dalam aspek teologi. Tetapi persoalan politik ini segera meningkat menjadi persoalan teologi ${ }^{5}$. Maka berbagai bentuk keragaman merupakan bentuk keniscayaan dalam kehidupan umat manusia. Rangkaian antropological constanst ${ }^{6}$ yang merupakan penjelmaan mahluk historis bagi setiap kehidupan manusia.

Kondisi tersebut sangat relevan sekali dengan keadaan Indonesia sekarang, konflik yang terjadi didasari permasalahan isu politik yang kemudian ditarik ke ranah teologi. Sehingga agama di jadikan justifikasi terhadap permasalahan tersebut. Sebagaimana Yayasan Bantuan Hukum Indonesia (YLBHI) telah mencatat, selama Januari 2020 hingga Mei 2020, terjadi 38 kasus penodaan agama di Indonesia. Ke-38 kasus tersebut tersebar di sejumlah provinsi, mayoritas di sulavesi Selatan ${ }^{7}$.

\footnotetext{
${ }^{1}$ Statistik, "Jumlah penduduk Indonesia Semester I 2020."

2 Statistik. "kewarganegaraan, suku bangsa, agama, dan bahasa sehari-hari penduduk Indonesia, katalog BPS: 21020032", h. 9".

${ }^{3}$ Khairiyah, "718 Bahasa Daerah di Indonesia Terlengkap Tahun 2020, pada www. cekaja.com ."

${ }^{4}$ Badri yatim, Sejarah peradaban Islam,(Jakarta: PT. Raja Grafindo Persada, 2010), h. 35-41.

${ }^{5}$ Harun Nasution, Teologi Islam: aliran-aliran, sejarah dan analisa perbandingan, (Jakarta: UIPress, 2015), h. 3, Muhammad Prophet and Stateman, (oxford University Press, 1996), h. 222/3, lihat, Shorter Encylopedia os islam, (Leiden, E.J. Brill, 1961), h. 534.

${ }^{6}$ Sugianto, "Toleransi Beragama Perspektif Wahdat Al-Wujūd Ibnu Arabi". (Indonesian Journal of Islamic Theology and Philosophy; UIN Raden Intan Lampung, 2019).

Fitria Chusna "38 Farisa, kasus penodaan Agama, https://nasional.kompas.com/read/2020/08/21/17062211/ylbhi-hingga-mei-2020-terjadi-38-kasuspenodaan-agama-mayoritas-di-sulsel?page=all"
} 
Konfilik tersebut akan berubah menjadi konflik Nasional, jika Isu agama di tarik ke ranah politik dan golongan, karena isu agama merupakan isu yang sangat mudah untuk menggiring emosi masyarakat ${ }^{8}$. Hal tesebut senada dengan pernyataan Greg Barton bahwa dengan menggunakan tindakan extrimisme dalam kepentingan pribadi sangatlah berbahaya, apalagi dipergunakan untuk kepentingan politik. Hal serupa juga dipaparkan oleh abdul Karim bahwa banyak aktor-aktor politik intelektual yang memanfaatkan agama sebagai cara untuk memperoleh dukungan. Ia juga menyebutkan dua hal yang dapat menyebabkan para aktor politik memanfaatkan agama untuk kepentingannya. Pertama, lemahnya basis ideologi yang dimiliki kebanyakan partai politik di Indonesia. Kekuatan-kekuatan politik elektoral sangat jarang memiliki fondasi ideologis yang kuat yang menyebabkan partai-partai politik tidak benar-benar memiliki basis ideologi yang jelas. Kedua, lemahnya programatik yang dimiliki partai-partai politik. Sehingga masyarakat tidak bisa membedakan program apa saja yang akan diusung oleh setiap partai politik ${ }^{9}$. Dalam kondisi seperti ini mereka akan memanfaatkan potensi politik identitas di dalam masyarakat untuk mempertegas siapa diri sendiri dan siapa yang lain, sehingga yang paling mudah dimanfaatkan adalah agama.

Agama secara bahasa berasal dari bahasa sansekerta, yaitu "a" yang memiliki arti tidak dan "gama" memiliki arti kacau. Maka agama secara etimologi memiliki arti tidak kacau, tidak rancu, tidak rusak atau menjadi baik ${ }^{10}$. Atas dasar makna tersebut dapat dipahami bahwa agama merupakan suatu aturan yang mengatur kehidupan manusia dalam berinteraksi dengan sang pencipta dan interaksi sosial dalam masyarakat.

Berbeda dari sudut pandang terminologi, banyak ahli yang memaparkan dari sudut ini, antara lain: Dradjat mendevinisikan agama merupakan ekspresi rasa terhadap sesuatu yang diyakini, bahwa ada suatu zat yang lebih tinggi dari pada manusia. Sementara Glock dan Stark membatasi pengertian agama pada

\footnotetext{
${ }^{8}$ Robert A. Baron and Nyla R. Branscombe, Social Psychology, (USA: Pearson, 2012), h. 13.

${ }^{9}$ Greg Barton dan Abdul Gaffar Karim, "modal dan agama dalam percaturan politik lokal di indonesia". Pusat studi Hal Asasi Manusia Universitas Islam Indonesia (PUSHAM UII), Lihat pada: https://www.uii.ac.id/menilik-isu-agama-dalam-dunia-politik/"

${ }^{10}$ Faisal Ismail, Paradigma Kebudayaan Islam: Studi Kritis dan Refleksi Historis, (Jogyakarta: Titian Illahi Press, 1997), h. 28.
} 
sistem simbol, sistem keyakinan, sistem nilai dan sistem perilaku yang terlembaga, yang keseluruhannya terpusat pada persoalan yang dihayati secara maknawi ${ }^{11}$.

Beralih dari batasan di atas mengenai batasan agama secara terminilogi, Clifford Geertz melihat agama dari sudut antropologi, bahwa agama menurutnya sebagai sebuah sistem simbol kepercayaan yang dihayati dalam hati dan menjadi dorongan yang kuat kemudian terefleksi dalam konsep tatanan umum dan dibungkus dengan pancaran faktual sehingga kondisi hati tetap tampak realistis ${ }^{12}$.

Dari konsep tersebut, bahwa tujuan luhur manusia dan agama menghendaki kedamaian dan komitmen terhadap anti kekerasan, lalu mengapa kekerasan agama itu kerap terjadi dengan korban yang tidak terhitung jumlahnya. Mengapa agama yang mengajarkan kesejukan, kedamaian, kesentosaan, kasih sayang dan nilai-nilai ideal lainnya, kemudian tampil dengan wajah yang keras, garang, dan menakutkan, agama kerap dihubungkan dengan radikalisme, ekstrimisme, bahkan terorisme. Agama dikaitkan dengan bom bunuh diri, pembantaian, penghancuran gedung, dan lain-lain yang menunjukan penampilan agama yang menakutkan.

Peran agama sebagai perekat heteroginitas dan perbedaan sudah lama dipertanyakan. Tidak dapat dipungkiri, bahwa manusia yang menghuni di muka bumi ini begitu heterogen terdiri dari berbagai suku, etnis, ras, penganut agama, kultur, peradaban dan sebagainya. Samuel P. Huntington mengatakan bahwa perbedaan tidak mesti konflik, dan konflik tidak mesti kekerasaan. Dalam dunia baru, konflik-konflik yang paling mudah menyebar dan sangat penting sekaligus paling berbahaya bukanlah konflik antar sosial, antar golongan kaya dengan miskin, atau antara kelompok-kkelompok ekonomi, tetapi antara orang-orang yang memiliki entitas budaya yang berbeda ${ }^{13}$. Namun, selama berabad-abad, perbedaan entitas agama telah menimbulkan konflik yang paling lama, paling luas, dan paling

\footnotetext{
${ }^{11}$ Zakiyah Dradjat, Ilmu Jiwa Agama, (Jakarta: Bulan Bintang, 2005), h. 10

${ }^{12}$ Geertz and Hardiman, The Interpretation of cultures : selected essays/ Kebudayaan dan Agama", (Jogjakarta: Kaisius, 1992), h. 5.

${ }_{13}^{13}$ Huntington, Benturan Antar Peradaban Dan Masa Depan Politik Dunia, (Yogyakarta: Qalam, 2000), h. 9.
} 
banyak memakan korban. Penilaian secara negatif, agama telah memberikan kontribusi terhadap konflik, penindasan dan kekerasan. Agama telah menjadi tirani, di mana atas nama Tuhan orang melakukkan kekerasan, menindas, melakukan ketidak adilan dan pembunuhan.

Mengacu kepada kontek kekinian, bentuk-bentuk konflik, kekerasan dan perang agama biasanya dihubungkan dengan bangkitnya fundamentalisme yang disebabkan oleh dominasi mayoritas, sehingga memunculkan barisan luar pagar. Salah satunya yakni fundamentalisme agama, yang mengekspresikan cita-cita sosial-politiknya dalam bentuk ekstrimisme dan kekerasan sebagai reaksi terhadap kondisi kehidupan yang menurutnya tidak ideal karena dominasi mayoritas. Hal ini senada dengan teori struktural-konflik, bahwa jika manusia tidak setara, maka manusia tidak hanya dihambat oleh norma-norma dan nilai-nilai yang dipelajari melalui sosialisasi juga melalui struktur ketidaksetaraan dalam masyarakat. Adapaun struktur ketidasetaraan antara lain: perbedaan kelompok etnik, muda dan tua, jumlah laki-laki dan perempuan, perbedaan profesi, perbedaan agama, dan seterusnya ${ }^{14}$.

Berbeda dengan berbagai pusat perhatian teori konflik berbasis ketidaksetaraan, dan bermacam-macam kemudahan yang mereka anggap tersebar tidak merata, teori tersebut memiliki kesamaan aksioma bahwa asal-usul dan persistensi struktur ketidaksetaraan terletak pada dominasi kelompok mayoritas atas kelompok minoritas. Disebut teori konflik demikian karena bagi teori-teori ini yang melekat pada masyarakat yang tidak setara adalah konflik kepentingan antara "yang punya" dan tidak berpunya"15.

Adapun upaya-upaya solutif untuk menyelesaikan permasalahan tersebut yaitu melalui perubahan cara pandang, dari fundementalis-eksklusif-ekstrimis menuju inklusif, pluralis dan multikulturalis. Bersebrangan dengan konsep fundamentalisme di atas, pluralisme juga lahir dari fenomena

\footnotetext{
${ }^{14}$ Pip Jones, Pengantar Teori-Teori Sosial Dari Teori Fungsionalisme Hingga Post-Modernisme, (Jakarta: Yayasan Obor, 2010), H.15.

15 Wes Sharrock, The Problem of Order, in Introducing Sociology, (harmondswort: Penguin, 1977), h. 515-516.
} 
konflik yang mengatasnamakan entitas-entitas budaya ${ }^{16}$ tertentu terutama agama ${ }^{17}$. Pada kontek agama, pluralisme adalah istilah khas dalam teologi. Berbeda dengan fundamentalisme, didevinisikan secara umum sebagai sikap mereka yang menolak menyesuaikan kepercayaan dengan kondisi-kondisi yang baru atau sikap stagnan dan membeku yang menolak seluruh pertumbuhan dan seluruh perkembanan ketika mereka menisbatkan diri mereka kepada turats, maka pluralisme didevinisikan secara umum sebagai sikap pluralis yang bisa terekspresi dalam macam-macam rumusan, misalnya "agamaagama lain adalah jalan yang sama-sama sah untuk mencapai kebenaran yang sama".

Demikian juga dalam menyikapi pluralisme beragama. Sikap yang seyogyanya dilakukan seseorang adalah dengan memahami dan menilai "yang" (agama) lain berdasarkan standar mereka sendiri serta memberi peluang bagi mereka untuk mengartikulasikan keyakinannya secara bebas. Sedangkan multikulturalisme secara sederhana dapat dipahami sebagai pengakuan, bahwa sebuah negara atau masyarakat adalah beragam dan majemuk. Sebaliknya, tidak ada satupun negara yang mengandung hanya kebudayaan nasional tunggal. Dengan demikian, multikulturalisme merupakan sunnattullah yang tidak dapat ditolak bagi setiap negara-negara di dunia.

Multikulturalisme dapat pula dipahami sebagai "kepercayaan" kepada normalitas dan penerapan keragaman. Pandangan dunia multikulturalisme seperti ini dapat dipandang sebagai titik tolak dan fondasi bagi kewarganegaraan yang berkeadaban. Di sini, multikulturalisme dapat dipandang sebagai landasan budaya tidak hanya bagi kewarganegaraan dan kewargaan, tetapi juga bagi pendidikan.

Secara teoritis, agama menganjurkan pemeluknya untuk berbuat baik antar sesama manusia bahkan makhluk lain yang ada di dunia ini, akan tetapi realitas berkata lain. Sehingga diperlukan suatu konsep yang moderat dalam beragama dan berinteraksi sosial. Berdasarkan realitas tersebut yakni hubungan

${ }^{16}$ Sikumbank and Ranjabar, Sistem Sosial Budaya Indonesia : Suatu Pengantar, (Bogor: Ghalia Indonesia, 2006), h. 20-23.

${ }^{17}$ Tasmuji, Ilmu Alamiah Dasar Ilmu Sosial Dasar Ilmu Budaya Dasar, (Surabaya; UIN Sunan Ampel Press), Cet. 8, h.160-165. 
antara agama dan budaya banyak para peneliti meneliti kondisi tersebut, di antaranya: Geertz ${ }^{18}$, woodward 19 , Andrew Beaty ${ }^{20}$, Nur Syam ${ }^{21}$, Budiwanti22, serta masih banyak peneliti-peneliti lain yang mengkaji fenomena agama.

Sedangkan yang bertemakan moderasi beragama antara lain: Alif Jabal Kurdi dan Nur Azka Inayatullah, "Islam Nusantara: solusi menyikapi problem radikallisme agama", dalam penelitiannya mereka menemukan bahwa dialektika budaya dan agama terjadi pada masa Rasulullah dalam menghadapi tradisi penduduk mekkah, sehingga konsep Islam Nusantara yang memadukan antara agama dan budaya tidak bertentangan dalam Islam ${ }^{23}$.

Michael Laffan, peneliti senior, membahas tentang "Sejarah Islam di Nusantara, berdasarkan penelitiannya, Sejarah Islam di Nusantara dikembangkan dengan sifat yang sangat lentur, tentatif, sinkretis, dan yang paling penting multi suara. Jika melihat dari kesimpulan Islam yang dipaparkan dalam bukunya, maka dapat di lihat bahwa yang potret adalah para ahli tareqat, yaitu Islam yang dikembangkan di nusantara oleh para ahli tarekat ${ }^{24}$.

Atas dasar data dan realitas tersebut, maka sudah seharusnya setiap orang yang beragama harus menampilkan ekspresi beragama yang moderat, yaitu mayoritas melindungi minoritas, yang kuat melindungi yang lemah dan seterusnya, sebagaimana dalam bukunya Gus Dur "Islamku, Islam Anda dan Islam Kita: Agama Masyarakat Negara Demokrasi"25. Adapun mengenai moderasi beargama secara konseptual sudah banyak yang melakukan penelitian secara kepustakaan sebagai basis teoritik, sedangkan secara kasus sosial masyarakat masih sangat sedikit sekali terutama model moderasi beragama yang

\footnotetext{
${ }^{18}$ Geertz, Abangan, Santri, Priyayi Dalam Masyarakat Jawa, (Jakarta: Dunia Pustaka Jaya, 1981).

${ }^{19}$ Woodward, Islam Jawa Kesalehan Normatif Versus Kebatinan, (Yogyakarta: Lkis, 2004) .

${ }^{20}$ Andrew Beatty, "Varieties of Javanese Religion. An Anthropological Account, (Cambridge: Cambride University, 1999)

${ }^{21}$ Syam, ISLAM PESISIR, (Yogyakarta: LkiS, 2005).

${ }^{22}$ ERNI BUDIWANTI, Islam Sasak; Wetu Telu versus Waktu Lima, (Yogyakarta: LkiS, 2000).

${ }^{23}$ Kurdi and Inayatussahara, "Islam Nusantara: Solusi Menyikapi Problem Radikalisme Agama", Jurnal Keislaman, vol 19.no. 1, Juli 2019, h. 55-76

${ }^{24}$ Michael Laffan, Sejarah Islam Di Nusantara, (Yogyakarta: bentang Pustaka, 2015), h. 267-270.

${ }^{25}$ abdur rahman wahid, Islamku, Islam Anda, Islam Kita: Agama Masyarakat Negara Demokrasi, (Jakarta: The Wahid Institut, 2006), h. 1-78. 
diterapkan dalam masyarakat yang mayoritas terhadap minoritas dan pluralitas. Atas dasar kekosongan iniliah, peneliti tertarik untuk membahas "Minoritas dalam Pangkuan Mayoritas: studi ekspresi moderasi beragama di Desa Rama Puja Lampung Timur".

Desa rama puja merupakan desa yang memiliki komposisi penduduk yang cukup hetrogren, dari aspek agama didominasi oleh umat muslim sekitar $80 \%$ sedangkan sisanya $20 \%$ adalah agama hindu dan Kristen protestan. Sedangkan dari aspek suku, terdiri dari suku Jawa, Bali, Sunda, Batak dan Lampung. Yang paling unik dari data tersebut adalah, walaupun Desa Rama Puja didominasi oleh umat muslim akan tetapi dari segi politik sangat terbuka sekali untuk non Muslim, ini terbukti dengan terpilihnya umat hindu sebagai kepala desa selama tiga periode berturutturut. ${ }^{26}$ Desa rama puja juga memiliki pondok pesantren ${ }^{27}$, pondok pesantren yang notabene sebagai tempat pengkaderan dan pendidikan bagi umat Islam, akan tetapi umat Islam Desa Rama Puja mampu menampilkan sikap yang sangat moderat tidak dibalut oleh sikap primordial mayoritas dalam berpolitik dan bermu'amalah ${ }^{28}$. Kemudian kurun dalam perjalanan yang cukup kesadaran sebagai asas kebersamaan menimbulkan berbagai reaksi yang saling menyokong satu dengan lainya. Adanya kemampuan daya tangkap dan empati ${ }^{29}$ dari kalangan masyarakat Muslim yang memicu keberagaman dalam keberagamaan menjadi corak beragama di wilayah tersebut.

Dari komposisi tersebut, sepertinya kondisi desa rama puja sebagai antitesa terhadap teori yang telah disebutkan di atas, yakni dari sudut teori konflik, bahwa berdasarkan teori tersebut, mayoritas etnis akan mendominasi etnis minoritas, akan teapi teori tersebut tidak berlaku untuk kondisi desa rama puja,

\footnotetext{
${ }^{26}$ Mustaqim merupakan warga Lampung Timur yang berdomisili di Desa Rama Puja, Wawancara, tanggal 14 Desember 2020.

${ }^{27}$ Nama pondok pesantren yang berada di desa rama puja yaitu pondok pesantren Tri Bakti AtTaqwa yang beralamat Desa Rama Puja, Raman Utara Kabupaten Lampung Timur, Lampung, 34154 yang didirikan oleh KH. Reden Rahmad Djoyo Ulomo pada tahun 1958.

${ }^{28}$ Mustaqim merupakan warga lampung timur yang berdomisili di desa rama puja, Wawancara, tanggal 14 Desember 2020.

29 Nazaruddin, Hidayat, and Andreas, "ANALISIS STRATEGI PEMASARAN DAN PELAYANAN DALAM UPAYA PENINGKATAN KUALITAS DAYA SAING BIRO PERJALANAN HAJI DAN UMROH PROSPEKTIF EKONOMI SYARI'AH (Studi Pada PT. Makkah Multazam Safir Dan Al Madinah), (Nizham Journal of Islamic Studies; IAIN Metro, 2020)."
} 
dimana desa rama puja didominasi oleh muslim akan tetapi dalam pemerintahan dipimpin oleh non muslim. Hal tersebut dapat dibuktikan dengan data di bawah ini.

Tabel 1. Jumlah Penduduk Menurut agama/penghayat Terhadap

Tuhan Yang Maha Esa Desa Rama Puja Lampung Timur

\begin{tabular}{|l|l|c|c|}
\hline No & \multicolumn{1}{|c|}{ Agama } & Tahun 2017 & Tahun 2018 \\
\hline 1 & Islam & 3.920 & 3.941 \\
2 & Kristen Protestan & 3 & 3 \\
3 & Kristen Katholik & 0 & 0 \\
4 & Hindu & 206 & 205 \\
5 & Budha & 0 & 0 \\
\hline 6 & Penganut/Pengayat & 0 & 0 \\
& Kepercayaan Terhadap & & \\
& Tuhan Yang Maha Esa & & 4.149 \\
\hline \multicolumn{2}{|l|}{ Jumlah Penduduk } & 4.129 & \\
\hline
\end{tabular}

Tabel 2. Struktur Desa Rama Puja Tahun 2014-Sekarang

\begin{tabular}{|c|l|l|l|}
\hline NO & \multicolumn{1}{|c|}{ NAMA } & \multicolumn{1}{|c|}{ JABATAN } & KETERANGAN \\
\hline 1 & WAYAN DASTRE & Kepala Desa & 2014- Sekarang \\
\hline 2 & SUTOYO & Sekretaris Desa & \\
\hline 3 & WAYAN SUJANA & $\begin{array}{l}\text { Bendahara } \\
\text { Desa }\end{array}$ & \\
\hline 4 & MULYANI & $\begin{array}{l}\text { Kasi } \\
\text { Pembangunan }\end{array}$ & \\
\hline 5 & M.FATONI & Kaur Umum & \\
\hline 6 & SAMIRAN & $\begin{array}{l}\text { Kasi } \\
\text { Pemerintahan }\end{array}$ & \\
\hline 7 & $\begin{array}{l}\text { NI PUTU PUJI } \\
\text { RAHAYU }\end{array}$ & $\begin{array}{l}\text { Kaur } \\
\text { Perencanaan }\end{array}$ & \\
\hline 8 & DULKAMIT & Kasi Kesra & \\
\hline 9 & SUGITO & Kadus 1 & \\
\hline 10 & SUPARMAN & Kadus 2 & \\
\hline 11 & SUTRISNO & Kadus 3 & \\
\hline 12 & SUPRIYANTO & Kadus 4 & \\
\hline & & & \\
\end{tabular}




\begin{tabular}{|l|l|l|l|}
\hline 13 & DWI LESTARI & Kadus 5 & \\
\hline 14 & AGUS RIANTO & Kadus 6 & \\
\hline 15 & SUTINAH & Kadus 7 & \\
\hline 16 & TUKAMDI,S.Pd & Ketua BPD & \\
\hline 17 & $\begin{array}{l}\text { NYOMAN } \\
\text { SUTASOMA,S.Pd }\end{array}$ & Ketua LPMD & \\
\hline 18 & SUPARDI & Ketua P3A & \\
\hline 19 & AHMAD DIMYATI & P3N & \\
\hline
\end{tabular}

Berdasasarkan data tersebut tampaklah kondisi masyarakat Rama Puja, sehingga memperkuat peneliti untuk meneliti lebih lanjut ekspresi moderasi beragama mayoritas dalam mengayomi minoritas.

\section{B. EKSPRESI BERAGAMA}

Membahas tentang ekspresi beragama atau moderasi beragama kelompok Muslim mayoritas terhadap non Muslim yang minoritas. Menjadikan kajian utamanya adalah hal-hal yang merupakan fakta lapangan, kemudian dilengkapi dengan kajian dan telaah literatur-literatur yang berkaitan dengan ekspresi moderasi beragama kelompok mayoritas terhadap minoritas sebagai landasan teoritisnya, khususnya yang berkaitan dengan ekspresi beragama yang kemudian teori-teori tersebut diuji di lapangan. Melihat agama sebagai fenomena yang dapat diamati dengan suatu pendekatan khusus yang disebut fenomenologi. Agama adalah sebuah fenomena yang kaya sekaligus sangat kompleks. Ia mengandung berbagai dimensi: ritual, doktrinal, etika, sosial dan experensial.

Berdasarkan pengertian tersebut, terdapat beberapa peneliti pendahulu di antaranya. Mun'im A. Sirry dalam Dilema Islam dilema demokrasi, ilmuwan kontemporer mereduksi beragam istilah mengenai keberagaman kaum Muslim, seperti: modernis, progresif, reformis, liberal, dan ekstremis, Islamis, fundamentalis, atau radikal. Di antara puspa ragam tipologi tersebut, yang cukup lazim dipakai untuk mendiskripsikan keberagaman kaum muslim dalam era dewasa ini adalah kaum fundamentalis dan kaum liberal. Peperangan keberagaman yang 
mempunyai kedekatan dengan fundamentalis dan liberal adalah puritan dan moderat.

Abuddin Nata dalam, peta keragaman Islam di Indonesia (2001) menggali sebanyak 12 bentuk gerakan teologi di Indonesia. Keduabelas gerakan teologi tersebut pada dasarnya mempunyai rujukan sejarah Islam, walaupun banyak di antaranya sangat sumir, yaitu Islam fundamentalis, Islam teologis-normatif, Islam eksklusif, Islam rasional, Islam tranformatif, Islam aktual, Islam kontekstual, Islam esoteris, Islam tradisional, Islam modernis, Islam kultural, Islam inklusif-plural.

Penelitian ini, karena domainnya adalah ekspresi moderasi beragama kaum mayoritas terhadap minoritas, maka tipe keberagaman yang dianggap relevan adalah tipe fundamentalis, modernis dan pluralis. Menurut karen Amstrong dalam The Battle For god (2001) dan Mun'in A Sirry dalam membendung militansi agama (2003), fundemantalisme didefinisikan sebagai suatu gerakan agama yang beraksi terhadap perubahan sisial dan menganggapnya sebagai krisis. Seperti dikatakan William montgomery dalam Fundamentalisme Islam dan modernitas (1997) adalah problematik dan tidak tepat. Juga dikemukakan oleh James Barr dalam Bukunya Fundamentalisme (1996). Kemudian beberapa konsep tentang fundamentalsime ini dirujuk kepada M. Imarah dalam Fundamentalisme dalam perspektif barat dan Islam (1999), fazlur Rahman dalam gelombang perubahan dalam Islam: studi tentang fundamentalsisme Islam (2000), Robert N. Bellah dalam beyond Belief esei-esei tentang Agama di dunia Modern (2000), Yusril Ihza Mahendra dalam Modernisme dan fundamentalisme dalam politik Islam (1999), Bassam Tibi dalam bukunya The Challenge of Fundamentalism: politik Islam and the new world disorder (1999), dan ahmad S Moussali dalam bukinya moderate and radical Islamic fundamentalism: the quest for modernity, legitimacy, and the Islamic state (1999).

Sedangkan tentang pluralisme dirujuk kepada Anis malik Thoha, tren Pluralisme Agama, tinjaun Kritis (2005), Riyal ka'bah, Nilai-nilai pluralisme dalam Islam, bingkai gagasan yang berserak, (2005), adian Husaini dalam majalah media dakwah edisi No. 358 tahun 2005, MUI dalam majalah Media Dakwah, No. 358 Ed. Sya'ban 1426 H/September 2005, frans Magnis 
Suseno, dalam bukunya menjadi saksi kristus di tengah masyarakat majemuk (2004), Greg Barton dalam gagasan Islam liberral di Indonesia pemikiran Neomodernisme Nurchalis Majid, Djohan Efendi, ahmad wahid dan abdurrahman wahid (1999).

Kemudian penelitian Thaib Kelian berjudul pemikiran intiqal dan maqmi dalam gerakan jamaah Tabligh (2007), pada penelitian tersebut, kelin mempelajari dan mengamati aktivitas "jamaah tabligh" dan membagi dua pola pemikiran yang mendasari aktifitas jamaah tersebut yaitu intiqal dan maqami. Menurut kelin, adalah sangat luas bila meneliti jamaah tabligh dari sisi pemikiran dan gerakan dakwahnya dengan medan kerjanya yang mondial, maka penulis hanya bisa memperkecil fokus penelitian untuk melihat aspek pemikiran intiqal dan maqami dari jamaah ini.

Gaya ekspresi yang dimunculkan dalam kehidupan merupakn sebuah daya yang secara alami akan mempengaruhi sebuah kebenaran. Dengan berbagai kajian yang mencakup berbagai sisi kebenaran tersebut yang secara matang akan memberikan keberpengaruhannya dalam menjelaskan segala permasalahan sesuai dengan data empiris ${ }^{30}$. Dengan berbagai teori kebenaran yang mencakup, kebenaran biasa, kebenran ilmu, kebenaran filsafat dan kebenaran agama ${ }^{31}$.

\section{SEJARAH DESA RAMA PUJA LAMPUNG TIMUR}

Desa Rama Puja dibuka oleh jawatan transmigrasi pada tahun 1958, oleh jawatan pembukaan tanah wilayah sukadana dengan membuka tanah-tanah yang masih berupa hutan rimba belantara, setelah dibuka kemudian didatangkan penduduk transmigrasi dari pulau jawa. Pada tanggal 12 Agustus 1958 Desa Rama Puja didatangi oleh transmigrasi dari rayon Solo, Yogyakarta, Banyumas, Jawa Timur, Jawa Tengah, Jawa Barat dan Bali sejumlah 500 kepala keluarga dengan jumlah jiwa 1.545 Orang.

Setelah kepadatan penduduk diatur, diatas dan dibenahi penempatanya oleh jawatan transmigrasi dibentuklah kepala rombongan tiap-tiap dusun dibawah jawatan transmigrasi, Nama

\footnotetext{
${ }^{30}$ Rahma Dwi Nopryana, "Filosofis Kebenaran Fiksi Sebagai Pengembangan Intelegensi Bagi Kehidupan Individu Manusia, (Jurnal Bimbingan Penyuluhan Islam; IAIN Metro, 2020)"

${ }^{31}$ Louis O.Kattsoff, Pengantar Filsafat, (Yogyakarta; Tiara Wacana Yogya, 2004), h. 5.
} 
Desa Rama Puja ini dahulunya adalah Desa dari wilayayah Kecamatan Seputih Raman Kabupaten Metro dibawah kewedanaan Sukadana. Pada bulan Desember 1958 Desa Rama Puja diadakan pemiliihan Kepala Kampung, calon Kepala Kampung tersebut adalah calon tunggal atas tunjukan jawatan transmigrasi dari Jawa Timur yang bernama S.Wiryo Rejo. Menjadi Kepala Kampung Rama Puja memimpin dengan baik dan dibantu oleh kepala rombongan tiap-tiap Dusun, setelah S.Wiryo Rejo memimpin selama 5 tahun pada taahun 1958-1964 diadakan pemilihan Kepala Desa Rama Puja, adapun calon tunggal bernama Musirin terpilih menjadi Kepala Desa. Desa Rama Puja mempunyai luas wilayah $1225 \mathrm{Ha}$, Pada saat ini penduduknya berjumlah 4.149 jiwa yang terdiri dari 1.237 Kepala Keluarga.

\section{EKSPRESI DALAM PERIBADATAN}

Desa rama puja merupakan desa yang memiliki komposisi penduduk yang cukup hetrogren, dari aspek agama didominasi oleh umat muslim sekitar 90\% sedangkan sisanya 10\% adalah agama hindu dan Kristen protestan. Sedangkan dari aspek suku, terdiri dari suku Jawa, Bali, Sunda, Batak dan Lampung. Yang paling unik dari data tersebut adalah, walaupun Desa Rama Puja didominasi oleh umat muslim akan tetapi dari segi politik sangat terbuka sekali untuk non muslim, ini terbukti dengan terpilihnya umat hindu sebagai kepala desa selama tiga periode berturutturut. $^{32}$ Desa rama puja juga memiliki pondok pesantren ${ }^{33}$, pondok pesantren yang notabene sebagai tempat pengkaderan dan pendidikan bagi Umat Islam, akan tetapi umat Islam Desa Rama Puja mampu menampilkan sikap yang sangat moderat tidak dibalut oleh sikap primordial mayoritas dalam berpolitik dan bermu'amalah ${ }^{34}$.

Dari komposisi tersebut, sepertinya kondisi desa rama puja sebagai antitesa terhadap teori yang telah disebutkan di atas,

32 Mustaqim merupakan warga Lampung Timur yang berdomisili di Desa Rama Puja, Wawancara, tanggal 14 Desember 2020.

${ }^{33}$ Nama pondok pesantren yang berada di desa rama puja yaitu pondok pesantren Tri Bakti At-Taqwa yang beralamat Desa Rama Puja, Raman Utara Kabupaten Lampung Timur, Lampung, 34154 yang didirikan oleh KH. Reden Rahmad Djoyo Ulomo pada tahun 1958.

34 Mustaqim merupakan warga lampung timur yang berdomisili di desa rama puja, Wawancara, tanggal 14 Desember 2020. 
yakni dari sudut teori konflik, bahwa berdasarkan teori tersebut, mayoritas etnis akan mendominasi etnis minoritas, akan tetapi teori tersebut tidak berlaku untuk kondisi desa rama puja, dimana desa rama puja didominasi oleh muslim akan tetapi dalam pemerintahan dipimpin oleh non muslim. Hal tersebut dapat dibuktikan dengan data di bawah ini.

Tabel 1. Jumlah Penduduk Menurut Agama Desa Rama Puja Lampung Timur

\begin{tabular}{llcc}
\hline No & \multicolumn{1}{c}{ Agama } & Tahun 2017 & Tahun 2018 \\
\hline 1 & Islam & 3.920 & 3.941 \\
2 & Kristen Protestan & 3 & 3 \\
3 & Kristen Katholik & 0 & 0 \\
4 & Hindu & 206 & 205 \\
5 & Budha & 0 & 0 \\
6 & Penganut/Pengayat & 0 & 0 \\
& Kepercayaan Terhadap & & \\
& Tuhan Yang Maha Esa & & 4.149 \\
& Jumlah Penduduk & 4.129 & \\
\hline
\end{tabular}

Berdasarkan jumlah penganut agama maka akan terlihat sarana peribadatan desa rama puja lampung timur. Adapun sarana peribadatan sebagai berikut:

Tabel 2. Sarana Peribadatan

\begin{tabular}{llcc}
\hline \multirow{2}{*}{ No } & \multirow{2}{*}{ Sarana Peribadatan } & Tahun 2017 & Tahun 2018 \\
\cline { 3 - 4 } 1 & Jumlah Masjid & Buah & Buah \\
2 & Jumlah Mushola & 6 & 6 \\
3 & Jumlah Gereja & 9 & 10 \\
4 & Jumlah Vihara & 1 & 1 \\
5 & Jumlah Pura & 0 & 0 \\
& & 0 & 0 \\
\hline
\end{tabular}

Tabel 3. Majlis Keagamaan Desa Rama Puja

\begin{tabular}{lccccc}
\hline \multirow{2}{N}{} & \multirow{2}{*}{ Uraian } & \multicolumn{2}{c}{ TAHUN 2017 } & \multicolumn{2}{c}{ TAHUN 2018 } \\
\cline { 3 - 6 } $\mathrm{o}$ & $\begin{array}{c}\text { Kelom } \\
\text { pok }\end{array}$ & Anggota & Kelompok & Anggota \\
\hline & Majlis Ta'lim & 17 & 725 & 17 & 730 \\
\hline
\end{tabular}




\begin{tabular}{|c|c|c|c|c|}
\hline 2 Majlis Gereja & 0 & 0 & 0 & 0 \\
\hline 3 Majlis Budha & 0 & 0 & 0 & 0 \\
\hline 4 Majlis Hindu & 0 & 0 & 0 & 0 \\
\hline 5 Remaja Masjid & 6 & 353 & 6 & 800 \\
\hline 6 Remaja gereja & 0 & 0 & 0 & 0 \\
\hline 7 Remaja Budha & 0 & 0 & 0 & 0 \\
\hline 8 Remaja Hindu & 0 & 0 & 1 & 0 \\
\hline
\end{tabular}

\section{E. KESIMPULAN}

Penelitian ini didasari dengan beberapa asumsi yang hendak diuji dan dikembangkan lebih lanjut. Asumsi-asumsi tersebut adalah mayoritas yang memiliki pemahaman yang moderat terutama teologinya sangat berperan dalam membentuk konstruksi sosial masyarakat yang moderat. Asumsi kedua, Komunitas Muslim yang moderat adalah bagian integral dengan lingkungan masyarakatnya sehingga faham moderat yang diamalkanya pasti berhubungan dengan konstruksi sosial masyarakat di mana dia hidup. Asumsi ke tiga, individu-individu dalam komunitas tersebut merupakan agen-agen yang mensosialisasikan konsep dari konsensus mayoritas.

Agen-agen tersebut sebagai manusia, dalam jiwanya tidak hanya memiliki unsur apriori yang rasional tetapi juga unsur apriori irasional ${ }^{35}$. Otto berpendapat, unsur apriori irasional adalah "kinsafan beragama", yaitu kesadaran terhadap zat yang maha Esa. Keinsafan atau kesadaran beragama merupakan kompetensi tersendiri. Scheller menamainya dengan sebutan kompetensi fitrah yang dimiliki oleh manusia ${ }^{36}$.

Fitrah beragama tersebut atau kesadaran manusia akan hierofani (tajali syuhudi) merupakan pengalaman yang hakiki, manusia sebagai fa'il mazazi dari zat yang maha Esa (Fa'il Haqiqi). ${ }^{37}$ Pembentuk pengalaman religius yaitu secaara ilahiyah

\footnotetext{
${ }^{35}$ Nico Syukur, Pengalaman Dan Motivasi Beragama, edisi Ke-2 (Yogyakarta: Kanisius, 1988), h. 27.

${ }^{36}$ Rudolf Otto, The Idea of Holy, (Hardmonswort: Pengguin Books, 1959), h. 192.

37 Ibnu 'Atoilah, Syarah Al Hikam, (haromain, th), h. 3, lihat, Nico Syukur, Pengalaman dan Motivasi beragama, edisi Ke-2(Yogyakarta: Kanisius, 1988), h.27
} 
(inheren dalam diri manusia atau faktor nativisme), faktor konstruksi sosial (faktor empirisme) dan faktor gabungan (konvergensi) $^{38}$. Faktor tersebut saling berhubungan secara interdepensi dalam artian dimensi esoterik dari suatu agama atau kepercayaan, pada dasarnya tidak berdiri sendiri, melainkan saling terkait dengan dimensi eksoteris atau di luar dirinya ${ }^{39}$. Begitu juga struktur sosial ikut berperan dalam membentuk pengalaman religius ${ }^{40}$.

Komposisi tersebut sangat penting untuk di analisa secara komprehensif dan transparan sebagai hasil akhir sebuah simpulan serta korelasi konstruksi para agen dengan pemahaman teologis dan konstruksi sosial masyarakat tempat mereka mengekspresikan konstruksi pemaknaan dalam bentuk gerakan moderasi beragama. Secara mainstream terdapat tiga trend sebagai hasil dari interaksi ketiga elemen, yakni: pola pikir fundamentalis-eksklusif, pluralinklusif dan multikultural. Berdasarkan uraian simpulan di atas, maka berikut ini dapat digambarkan alur atau kerangkanya seperti di bawah ini:

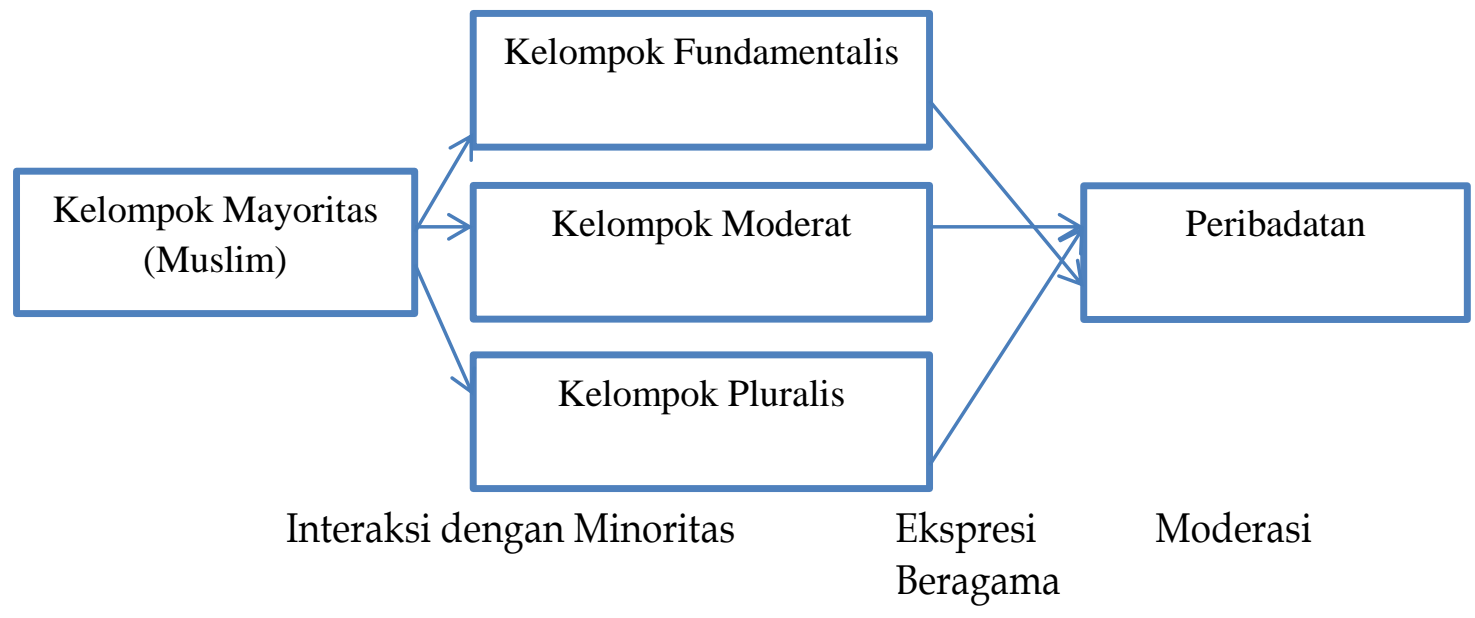

\footnotetext{
${ }^{38}$ Robert A. Baron and Nyla R. Branscombe, Social Psychology.

${ }^{39}$ Pip Jones, Pengantar Teori-Teori Sosial: Dari Teori Fungsionalisme Hingga Post-Modernisme, (Jakarta: Buku Obor, 2010), H. 8-12.

${ }^{40}$ Anthoni Giddens, Teori Strukturasi: Dasar-Dasar Pembentukan Struktur Sosial Masyarakat, (Yogyakarta: Pustaka Pelajar, 2010), h. 250-259.
} 


\section{DAFTAR PUSTAKA}

abdur rahman wahid. Islamku, Islam Anda, Islam Kita: Agama Masyarakat Negara Demokrasi. Indonesia, jakarta: The Wahid Institut, 2006.

Andrew Beatty. "Varieties of Javanese Religion. An Anthropological Account." L'HOMME Oktober-De, no. Intellectuels en diaspora et théories nomades (1999): 295-97. https://doi.org/https://doi.org/10.4000/lhomme.2767.

Anthoni Giddens. Teori Strukturasi: Dasar-Dasar Pembentukan Struktur Sosial Masyarakat. Indonesia, yogyakarta: Pustaka Pelajar, 2010.

Badri yatim. Sejarah Peradaban Islam. Indonesia, jakarta: PT. Raja Grafindo Persada, 2010.

Erni Budiwanti. Islam Sasak; Wetu Telu versus Waktu Lima. Indonesia: LKIS, 2000. http://www.lkis.co.id/produk-814islamsasakwetuteluversuswaktulima.html.

Faisal Ismail. Paradigma Kebudayaan Islam: Studi Kritis Dan Refleksi Historis. Indonesia, yogyakarta: Titian Ilahi Press, 1997. https://www.unida.ac.id/elibrary/index.php?p=show_detail\&i $\mathrm{d}=7962 \&$ keywords $=$.

Fitria Chusna Farisa. "38 Kasus Penodaan Agama." Indonesia: kompas.com, 2020. https:/ / nasional.kompas.com/read/2020/08/21/17062211/ylbh i-hingga-mei-2020-terjadi-38-kasus-penodaan-agama-mayoritasdi-sulsel?page $=$ all.

Geertz, Clifford. Abangan, Santri, Priyayi Dalam Masyarakat Jawa. Indonesia, jakarta: Pustaka Jaya, 1981. https:/ /opac.perpusnas.go.id/DetailOpac.aspx?id=122611.

Geertz, Clifford, and Fransisco Budi Hardiman. The Interpretation of Cultures: Selected Essays/ Kebudayaan Dan Agama. Kanisius, 1992. https:/ /opac.perpusnas.go.id/DetailOpac.aspx?id=267319. Greg Barton dan Abdul Gaffar Karim. "Modal Dan Agama Dalam Percaturan Politik Lokal Di Indonesia." In Modal Dan Agama Dalam Percaturan Politik Lokal Di Indonesia. Indonesia, yogyakarta: $\quad$ www.uii.ac.id, 2020.

https:// www.uii.ac.id/menilik-isu-agama-dalam-duniapolitik/.

Harun Nasution. Teologi Islam: Aliran-Aliran, Sejarah Dan Analisa Moderasi Beragama Sebagai Jalan.... Sugianto $\mathcal{E}$ Rahmat Hidayat 
Perbandingan. Jakarta Indonesia: UI-Press; oxford University Press and E.J. Brill, 2015.

Huntington, Samuel P. Benturan Antar Peradaban Dan Masa Depan

Politik Dunia. Indonesia, yogyakarta: Qalam, 2003. http:/ / lib.ui.ac.id/detail?id=24810.

Khairiyah, Vera. "718 Bahasa Daerah Di Indonesia Terlengkap Tahun 2020." indonesia: www. cekaja.com, 2020. www. cekaja.com.

Kurdi, Alif Jabal, and Nur Azka Inayatussahara. "Islam Nusantara: Solusi Menyikapi Problem Radikalisme Agama." Analisis: Jurnal Studi Keislaman 19, no. 1 (2019): 55-76. https://doi.org/10.24042/ajsk.v19i1.3374.

Louis O.Kattsoff. Pengantar Filsafat. Indonesia, yogyakarta: Yogyakarta; Tiara Wacana Yogya, 1992.

Michael Laffan. Sejarah Islam Di Nusantara. 1st ed. Indonesia: PT Bentang Pustaka, 2015.

Nazaruddin, Nasrun, Rahmat Hidayat, and Ricco Andreas. "Analisis Strategi Pemasaran Dan Pelayanan Dalam Upaya Peningkatan Kualitas Daya Saing Biro Perjalanan Haji Dan Umroh Prospektif Ekonomi Syari'ah (Studi Pada PT. Makkah Multazam Safir Dan Al Madinah)." Nizham Journal of Islamic Studies 8, no. 01 (2020): 1. https://doi.org/10.32332/nizham.v8i01.2090.

Nico Syukur. Pengalaman Dan Motivasi Beragama. Indonesia, yogyakarta: Kanisius, 1988. http:/ / adl.aptik.or.id/default.aspx?tabID=61\&src=k\&id=18006. pip jones, dkk. Pengantar Teori-Teori Sosial: Dari Teori Fungsionalisme Hingga Post-Modernisme. Indonesia: Yayasan Pustaka Obor Indonesia, 2010. http://obor.or.id/Pengantarteori-teori-sosial-teori-fungsionalisme-post-modernisme.

Rahma Dwi Nopryana, Wahyudin,. "Filosofis Kebenaran Fiksi Sebagai Pengembangan Intelegensi Bagi Kehidupan Individu Manusia." Jurnal Bimbingan Penyuluhan Islam 1, no. 2 (2020): 269. https:// doi.org/10.32332/jbpi.v1i2.1723.

Robert A. Baron and Nyla R. Branscombe. Social Psychology. USA:

PEARSON, 2012. https://www.pearson.com/us/highereducation/ product/Baron-Social-Psychology-13th-

Edition/9780205205585.html.

Rudolf Otto. The Idea of Holy. English, Hardmonswort: Pengguin Books, 1959.

Sikumbank, Risman F., and Jacobus Ranjabar. Sistem Sosial Budaya 
Indonesia: Suatu Pengantar. Indonesia, BOGOR: Ghalia Indonesia, 2006. https:/ /opac.perpusnas.go.id/DetailOpac.aspx?id=247705.

Statistik, Badan Pusat Statistik Indonesia 2020. "Jumlah Penduduk Indonesia 2020." Indonesia, n.d. https://www.bps.go.id/pressrelease/2021/01/21/1854/hasilsensus-penduduk-2020.html.

Sugianto, Sugianto. “Toleransi Beragama Perspektif Wahdat AlWujūd Ibnu Arabi." Indonesian Journal of Islamic Theology and Philosophy 1, no. 2 (2020): 85-100. https://doi.org/10.24042/ijitp.v1i2.5076.

Syam, Nur. Islam Pesisir. Indonesia: LKIS, 2005. http://www.lkis.co.id/produk-813-islampesisir.html.

Tasmuji, dkk. Ilmu Alamiah Dasar Ilmu Sosial Dasar Ilmu Budaya Dasar. Cet-8. indonesia, surabaya: UIN Sunan Ampel Press, 2018. http:// digilib.uinsby.ac.id/32854/1/Buku - IAD ISD IBD.pdf.

Wes Sharrock. The Problem of Order, in Introducing Sociology. Edited by Peter Worsley Et Al. Baston USA: harmondswort: Penguin, 1970.

Woodward, Mark R. Islam Jawa Kesalehan Normatif versus Kebatinan. Cet 1. indonesia, semarang: LKIS, 2017. https:/ / onesearch.id/Record/IOS13428.INLIS000000000872896\# description. 